\title{
OS SÍMBOLOS E SUAS REPRESENTAÇÕES NA PROPAGANDA TELEVISIVA: ANÁLISE SEMIÓTICA DO VT "THE ENTRANCE" DA HEINEKEN
}

\author{
ELISANGELA ANTUNES \\ UNIVERSIDADE DO OESTE DE SANTA CATARINA \\ JOAÇABA, SANTA CATARINA, BRASIL \\ E-MAIL: ELISANTUNES_@HOTMAIL.COM. \\ SILVIA SPAGNOL SIMI DOS SANTOS \\ UNIVERSIDADE DO OESTE DE SANTA CATARINA \\ JOAÇABA, SANTA CATARINA, BRASIL \\ E-MAIL: SILVIA.SIMI@UNOESC.EDU.BR.
}


OS SÍMBOLOS E SUAS REPRESENTAÇÕES NA PROPAGANDA TELEVISIVA: ANÁLISE SEMIÓTICA DO VÍDEO “THE ENTRANCE” DA HEINEKEN

Resumo: O presente estudo objetivou analisar como os elementos semióticos, inseridos no VT "The Entrance", da campanha "Open Your World" da Heineken, veiculam significados relacionados à marca no processo de persuasão e sedução do consumidor. É um estudo teórico-descritivo centrado na teoria semiótica de Peirce considerando outras áreas do conhecimento como a sinestesia, significação e linguagem televisiva.

Palavras-chave: Semiótica; Publicidade; Televisão.

LOS SÍMBOLOS Y SUS REPRESENTACIONES EN LA PUBLICIDAD TELEVISIVA: ANÁLISIS SEMIÓTICO DEL VIDEO “THE ENTRANCE” HEINEKEN

Resumen: Este estudio tuvo como objetivo analizar cómo los elementos semióticos, que en VT" The Entrance", de la campaña "Open Your World" Heineken, transmiten significados relacionados con la marca en el proceso de persuasión y seducción del consumidor. Es un estudio teórico descriptivo centrado en la teoría semiótica de Peirce considerando otras áreas como la sinestesia, significado y lenguaje televisivo.

Palabras clave: Semiótica; Publicidad; Televisión.

THE SYMBOLS AND THEIR REPRESENTATIONS IN TELEVISION ADVERTISING: SEMIOTIC ANALYSIS OF THE VIDEO "THE ENTRANCE" HEINEKEN

Abstract: This study aimed to analyze how the semiotic elements, which in VT "The Entrance", the campaign "Open Your World" Heineken, convey meanings related to the brand in the process of persuasion and seduction consumer. It is a theoretical descriptive study focused on semiotic theory of Peirce considering other areas as synesthesia, meaning and television language.

Keywords: Semiotics; Advertising; Television. 


\section{NTRODUÇÃO}

O interesse da pesquisa foi direcionado pela busca em compreender como a propaganda televisiva utiliza-se da semiótica para produzir suas mensagens, as representações que determinados símbolos estão aptos a produzir e como ocorre o processo de sinestesia e de produção de significados para transmitir o conceito da marca e do produto.

Ao serem analisados e classificados, os signos podem ser interpretados e, a partir dessa interpretação, é possível identificar como foram utilizados para produzir algum efeito no receptor. Também é possível entender a relação do signo, seu objeto e sua significação, compreendendo, dessa forma, quais os valores agregados na marca e que são emitidos aos consumidores.

\section{SEMIÓTICA: A TEORIA GERAL DOS SIGNOS}

Antes mesmo de iniciar e aprofundar os estudos sobre as facetas da semiótica é necessário compreender sua origem e do que trata essa teoria. Quem explica claramente os conceitos da semiótica é a autora Santaella (1986, p. 7), ao afirmar que "semiótica vem da raiz grega semeion, que quer dizer signo."

A semiótica peirceana, tem como fundador Charles Sanders Peirce (18391941), filósofo e matemático norte-americano que, ao criar essa teoria, possibilitou sua aplicação em diversas áreas do conhecimento, como a Filosofia, a Sociologia e a Comunicação.

A semiótica nos permite categorizar sons, imagens, palavras em todas as suas manifestações. Santaella (2008, p. 59) afirma que semiótica "é a teoria de todos os tipos de signos, sinais, códigos e linguagens." Portanto, conceitualmente, a semiótica é a ciência geral de todas as linguagens. Uma teoria pela qual é possível analisar e interpretar todos os signos presentes em todos os tipos de linguagem.

Assim, a teoria semiótica de Peirce é baseada na noção de signo, que significa "uma coisa que representa outra coisa para alguém" (PEREZ, 2004, p. 141). O signo só pode ser considerado signo quando tem o poder de substituir ou representar algo diferente dele, ou seja, o seu objeto. 
Os símbolos e suas representações na propaganda televisiva: análise semiótica do VT “The Entrance” da Heineken

\subsection{Tricotomias do Signo}

Para esclarecer o conceito de signo, o alicerce da teoria semiótica de Peirce, utilizamos o seu legado descrito na obra de Santaella. Ela explica que o signo é qualquer coisa que representa outra coisa, chamada de objeto do signo e que produz um efeito, chamado de interpretante. (SANTAELLA, 2000, p. 18).

O signo possui uma função triádica por ser um elemento que se correlaciona com outros três elementos: o representamen, o objeto e o interpretante. Peirce apud Santaella (2000, p. 18, grifo do autor) diz que "Um signo é qualquer coisa que está relacionada a uma Segunda coisa, seu Objeto, com respeito a uma qualidade de tal modo a trazer uma Terceira coisa, seu Interpretante."

Sendo um signo um elemento que se correlaciona com o representamen, o objeto e o interpretante, Peirce (2008) desenvolveu três categorias universais presentes em todos os fenômenos, as quais chamou de primeiridade, secundidade e terceiridade.

A primeiridade relaciona-se com qualidade, características, sentimentos e sensações, algo imediato e que não se relaciona à outra coisa. Sobre primeiridade, Santaella (1986, p. 57) diz que "Trata-se de uma consciência imediata tal qual é. Nenhuma outra coisa senão qualidade de ser e sentir."

A segunda categoria, ou secundidade, diz respeito às relações, reações e ações, está ligada aos fatos e ideias de dependência. Essa categoria é caracterizada pelo mundo real, reativo e pensável (SANTAELLA, 1986, 62). A secundidade absorve os fatos, uma existência real onde há a corporificação da qualidade encontrada na categoria da primeiridade.

A terceiridade representa a generalidade, as leis e a interpretação completa do signo, do seu objeto e dos efeitos que está apto a produzir. Nessa categoria, ocorre a aproximação do primeiro a um segundo; podemos dizer que há uma associação de ideias onde uma qualidade é atrelada a uma existência real, obrigando-nos a representarmos e interpretarmos o mundo.

Portanto, Peirce dividiu os signos de acordo com as três categorias fundamentais e conforme o signo em si mesmo, em seu objeto e no seu interpretante, pelos quais, na primeiridade, será uma mera qualidade, ou seja, um qualissigno, um ícone ou um rema. Na secundidade, o signo será uma existência real: um sinsigno, um índice ou um dicente. E na terceiridade, o signo será uma lei geral: um legissigno, um símbolo ou um argumento. As- 
sim, tudo que percebemos passa por uma carga de interpretação fruto de uma mediação construída através do signo.

\subsection{As dez classes do signo}

As combinações dos determinantes do signo, ou seja, as combinações resultantes das suas relações com o representamen, com objeto e com seu interpretante, desencadeiam em dez classes dos signos que serão explicadas a seguir e pelas quais é possível desenvolver estudos de processos comunicacionais. As dez classes sígnicas são são: qualisigno icônico remático; sinsigno icônico remático; sinsigno indicativo remático; sinsigno indicativo dicente; legisigno icônico remático; legisigno indicativo remático; legisigno indicativo dicente; legisigno simbólico remático; legisigno simbólico dicente e legisigno simbólico argumental.

Diante disso, os estudos e análises realizadas por Peirce proporcionaram um método lógico pelo qual é possível classificar um signo. Seu objetivo era fundar uma ciência geral dos signos que pudesse servir de alicerce para outras ciências, para a experiência humana e sua comunicação.

Por sua importância nesse processo comunicacional, o símbolo merece uma atenção específica. Dessa maneira, serão apresentados a seguir, os conceitos de signo e publicidade a fim de obtermos um estudo alicerçado na importância da inclusão dos símbolos na publicidade para produzir significados e valores de marca.

\subsection{Simbolismo e publicidade}

Em todo símbolo deve haver uma relação de semelhança, ou seja, o símbolo deve possuir um grau de iconicidade que representa um objeto simbolizado. Nöth (2008, p. 83) explica que "o símbolo é o signo da segunda tricotomia que participa da categoria de terceiridade. Cada símbolo é, portanto e ao mesmo tempo, um legi-signo."

Assim, um símbolo é tudo aquilo que representa alguma coisa por meio de uma convenção, analogia ou leis gerais definidas. O símbolo é uma representação por ressaltar a concepção de seu objeto, como por exemplo, uma aliança, que consideramos símbolo de casamento.

A relação entre símbolo e comunicação foi descrita por Umberto Eco como a teoria dos códigos. Ele utiliza a palavra "códigos" porque sua teoria foi construída com base dos processos de informação e de comunicação. 
Os símbolos e suas representações na propaganda televisiva: análise semiótica do VT “The Entrance” da Heineken

Dessa maneira, como código, Eco (1968. p. 130) define "qualquer sistema de símbolos que, por consenso prévio entre destinador e destinatário, é usado para representar e transmitir qualquer informação." Então, a semiótica tem o poder fundamental de fornecer um método de análise para os processos de comunicação.

A partir do conhecimento do conceito de signo, é preciso definir o que é publicidade para compreender a relação entre os dois. Segundo a definição Associação Americana de Marketing descrita na obra de Santaella e Nöth (2010, p. 13), a publicidade "é uma forma não pessoal de apresentação e promoção paga de ideias, mercadorias e serviços por um financiador identificado."

A intenção da publicidade é atrair, seduzir e persuadir o consumidor em relação aos valores inseridos na marca e na publicidade a fim de fazê-lo comprar o produto. A atração ou sugestão corresponde ao nível da primeiridade bem como a sedução corresponde a secundidade e a persuasão representa a terceiridade (SANTAELLA E NÖTH, 2010, p. 85).

As marcas passam a ser mais que nomes, são ideologias, valores e ideias que são consumidas por pessoas que refletem essa marca. "As marcas expressam, se dão a ver, se mostram de diversas maneiras, com o objetivo de potencializar seus efeitos de sentido". (PEREZ, 2004, p.47)

Dessa forma, é necessário não só analisar os símbolos inseridos na publicidade, mas também qual o seu poder de representação, quais os valores estão agregados na marca e como eles foram construídos através dos signos.

\section{PRODUÇÃO DE SENTIDO NA PROPAGANDA TELEVISIVA}

Ao atuar como meio de mudança de hábitos e consumo, a televisão insere na vida das pessoas ideologias, formas de pensar e ver o mundo, que são contribuintes para uma mudança de comportamento ou uma reflexão sobre a mensagem emitida.

A propaganda utiliza-se amplamente desse meio por atingir diferentes pessoas, de diferentes idades e classes sociais. Portanto, facilita que o anunciante esteja mais próximo do seu público e conquiste novos mercados, transmitindo valores e experiências a quem recebe a sua mensagem.

Isso faz com que as marcas sejam mais do que um simples nome, seu conceito traz consigo uma representação e um valor conquistados e inseridos nas suas mensagens publicitárias. Como afirma Tavares (1998, p.17), 
a marca representa muito mais que o produto, pois em suas propagandas produzem valores como status, conforto e poder, fazendo que as pessoas adquiram o produto por causa de sua marca.

Diante disso, a publicidade, especialmente os comerciais de televisão, por serem carregados de signos e valores que agregam à marca, devido à possibilidade da junção de diversos elementos; são essenciais na produção de sentidos e significados. Eles possuem a função de provocar uma percepção positiva da marca no imaginário do consumidor.

É por esse motivo que no processo de produção dos comerciais de televisão deve haver a conciliação entre som, imagem, movimento e outros efeitos, a fim de produzir representações para o público-alvo. Assim, a televisão destaca-se como um meio multissensorial que quando possui elementos trabalhados com eficácia atraem a atenção do público, nos expondo à multiplicidade de formatos, linguagens e formas diversificadas de produção audiovisual, as quais apresentam uma enorme integração entre imagem e som.

Conforme Santaella (2012, p. 139-142), é por meio de três estratégias principais que a linguagem publicitária é desenvolvida com o objetivo de ser eficaz: a sugestão, e sedução e a persuasão. A estratégia de sugestão atrai o receptor para dentro da mensagem e torná-lo parte dos sentidos que a mensagem deseja transmitir. Na estratégia de sedução a intenção é despertar um desejo no receptor da mensagem, fazendo um intermédio entre razão e emoção. Na estratégia de persuasão busca-se convencer o receptor a tomar uma atitude positiva em relação à mensagem.

Além disso, é possível identificar que por meio de construções e combinações de diferentes linguagens, a publicidade provoca emoções, desejos e expectativas que são acentuadas na televisão pela sua característica multissensorial, fornecendo condições para que a mensagem seja transmitida com maior eficiência, na medida em que atrai a atenção e os sentidos do consumidor.

\section{ANÁLISE DO VT "THE ENTRANCE" DA HEINEKEN}

A intenção dessa pesquisa foi obter um estudo alicerçado nos elementos semióticos, ou seja, na utilização dos signos no VT "The Entrance" da campanha "Abra seu mundo" da cerveja Heineken e suas representações simbólicas, demonstrando como a marca e o produto são expostos através 
Os símbolos e suas representações na propaganda televisiva: análise semiótica do VT “The Entrance” da Heineken

de signos, que produzem valores e efeitos nos consumidores, e como as representações simbólicas segmentam e diferenciam o público-alvo, de uma realidade cultural e social específica.

Dessa forma foi realizado um estudo do VT e dos elementos semióticos contidos nele, por meio da decupagem, ou seja, da divisão do comercial em cenas e da classificação dos signos com base na teoria proposta por Peirce. Portanto, foi realizada uma abordagem específica do tema com a intenção de contribuir significativamente para o estudo da semiótica, em especial, da semiótica e as propagandas televisivas.

A pesquisa em questão foi descritiva, tendo como objetivo proporcionar familiaridade com o problema com vista a torná-lo mais explícito. Dessa forma, é uma análise do VT a partir dos conceito básicos descritos por Peirce.

\subsection{Classificação dos Signos}

Do início ao final do VT, mantem-se a trilha sonora de uma banda excêntrica e com um ritmo contagiante e divertido ao mesmo tempo em que é discreto e linear. A música se encaixa na sétima classe dos signos, sendo um Sinsigno indicativo remático, pois possui um som alto que embala a festa e contribui para o clima de diversão e proporciona o crescimento do personagem principal. No entanto, não conhecemos os detalhes da canção e da banda. A trilha insere perfeitamente o clima em todas as cenas, auxiliando na propagação da mensagem do VT, uma vez que, quando começa a tocar provoca envolvimento e o clima de diversão propiciado pela festa, sendo que o som completa as imagens.

As cores inseridas no VT também são um quesito de extrema importância para a composição e análise do VT, porque além de carregarem símbolos possuem um enorme potencial psicológico. No início do VT da Heineken, a cor predominante são as cores sóbrias das paredes e das roupas dos convidados, que representam o requinte da festa e dos convidados. No entanto, na medida em que as situações e o personagem principal evoluem, surgem cores mais vivas, na roupa, principalmente das mulheres, denotando aos poucos, ao receptor, o sentimento de alegria e diversão.

Dessa maneira, a cor exerce uma função de expressar o sentimento e a construção do significado de toda a cena, além de ser um símbolo à medida que constrói a linguagem e transmite a mensagem. Segundo Peirce (2008) a cor está inserida na primeira classe dos signos e, portanto, é um qualissigno 
icônico remático, pois é uma apenas uma qualidade de sentimento.

Além disso, as cores são amplamente utilizadas da publicidade, inclusive nas logomarcas, escolhidas pelas associações específicas que elas transmitem. Perez (2004, p. 78) diz: "Além da mera identificação e associação, a cor pode ser usada para criar experiências". Dessa forma, as cores, como formas de linguagem visual, provocam emoções no ser humano e torna-se um elemento fundamental no processo de sugestão, em que os receptores da mensagem são inseridos nela, fazendo-os sentir o que os personagens estão sentindo.

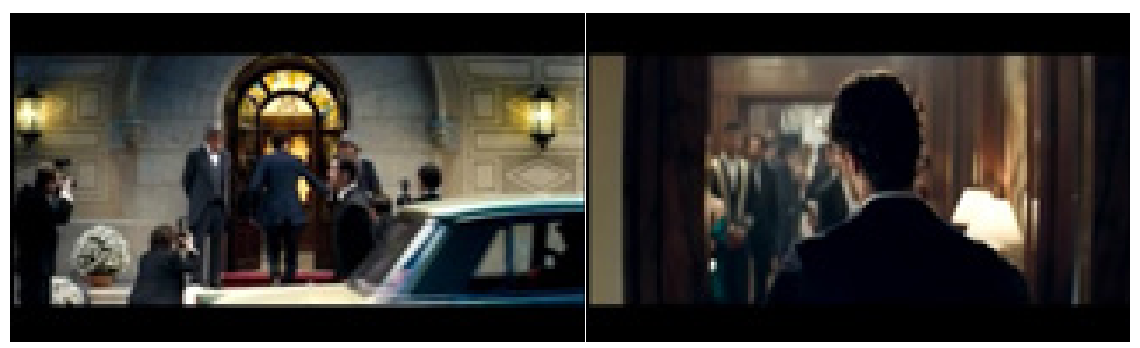

Figura 01 - Decupagem da Cena 01 Fonte: Heineken (2014).

Na cena um do VT, um homem bem vestido chega a uma festa em um carro luxuoso. Ele parece gentil ao cumprimentar os homens que estão na posta da casa, também luxuosa, onde a festa está acontecendo. Portando, as imagens do homem entrando na casa são um sinsigno, algo acontecendo como um existente real. É também um índice, pois indicam que lá dentro acontece um evento de grande porte, pois ele está bem vestido, ou seja, indicam como é esse existente real e é um rema, já que não sabemos o que realmente está acontecendo lá dentro, inserindo esses signos na classe do sinsigno indicativo remático.

Nessa cena está inserido o conceito de status, fazendo referência às práticas de consumo impregnadas nos símbolos e no campo sociocultural. O processo de criação de valor, o sentido e os símbolos são adquiridos pelos mecanismos estratégicos da marca (PEREZ, 2004, p. 134). É por esse motivo que as marcas precisam produzir sentido e significado na sua publicidade e a televisão é um meio que possui recursos essenciais para essa produção de representações simbólicas. 
Os símbolos e suas representações na propaganda televisiva: análise semiótica do VT “The Entrance” da Heineken

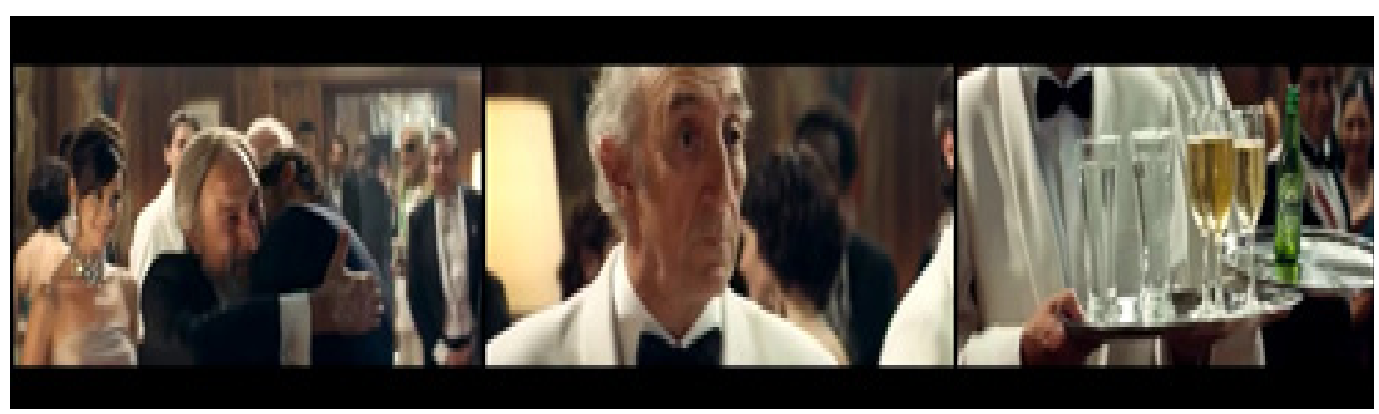

Figura 02 - Decupagem da Cena 02 Fonte: Heineken (2014).

Na cena dois percebemos que o homem entra em um local onde há outras diversas pessoas, bem vestidas, mas não sabemos exatamente o que está acontecendo no interior da casa. Essa cena classifica-se na quarta classe dos signos e é, portanto, um sinsigno indicativo dicente, pois o homem entrando no local e encontrando várias pessoas é um fato real acontecendo, as pessoas estarem bem vestidas é um índice de que um evento importante está acontecendo naquele local, e o início dá música nos remete a uma festa, um ambiente de animação. Esse clima sugere que o expectador entre junto com o homem na casa e participe da festa e desse momento de diversão, provocando uma interação por parte do público.

Ainda na cena dois, logo que o homem entra na festa, ele demonstra conhecer o senhor que o recebe, cumprimentando-o carinhosamente, podendo ser classificado como legissigno simbólico remático, pois o homem que entra na festa cumprimenta primeiramente o homem mais velho em sinal de respeito. A compreensão desse ato é uma associação de ideias, um pensamento articulado em nossa mente e, por esse motivo, é simbólico.

Assim, é possível identificar nessa cena uma das estratégias principais da linguagem publicitária definidas por Santaella (2012, p. 139-142): a sugestão. Nessa mensagem, a garrafa de Heineken é o que se destaca, sugerindo ao consumidor quem é o anunciante, incluindo o receptor no interior da mensagem tornando-o parte daquilo que é sentido. 

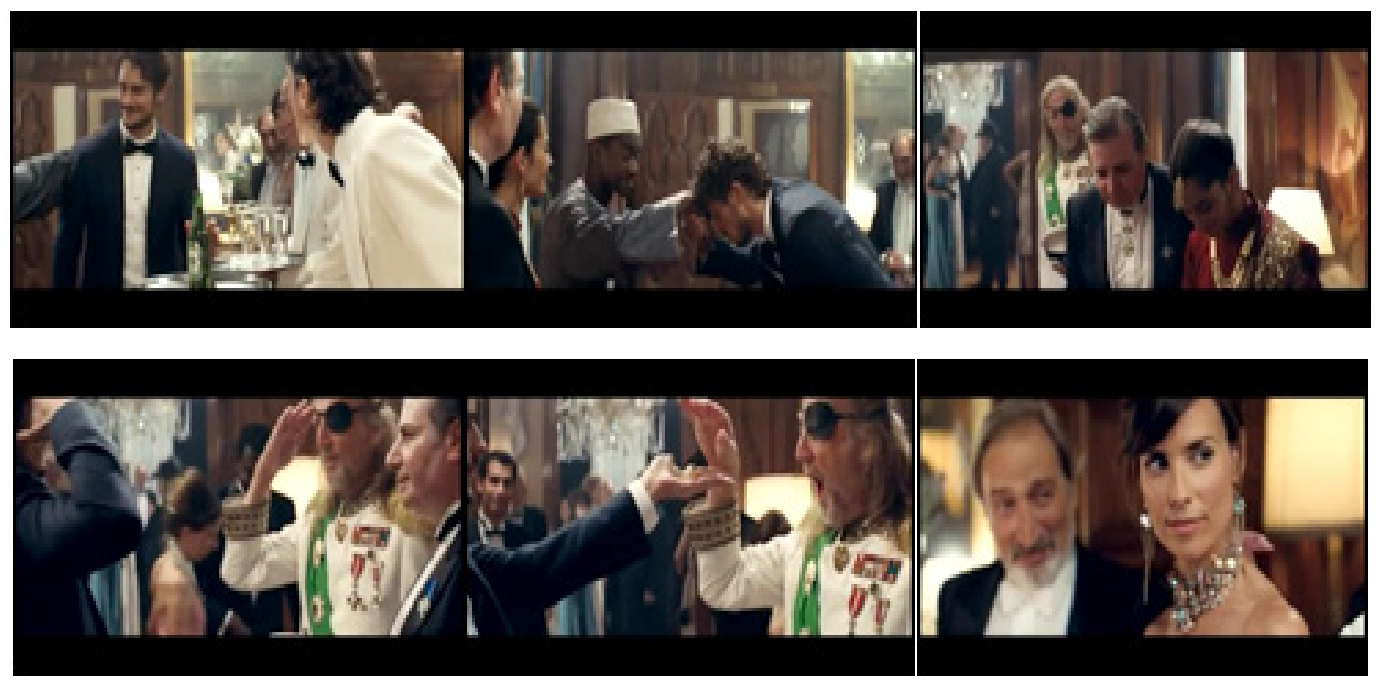

Figura 03 - Decupagem da Cena 03

Fonte: Heineken (2014).

Logo em seguida, na cena três, surge o garçom que oferece uma bebida ao personagem principal: em uma bandeja há bebidas em taças e em outra apenas uma garrafa de Heineken para a qual o homem se dirige para pegá-la. Essa cena é um sinsigno dicente, pois é um fato acontecendo realmente como um signo, onde a Heineken está em uma bandeja, sem dividi-la com outras bebidas, transmitindo a ideia de exclusividade e seduzindo o expectador.

Nesse caso, a combinação entre cor da garrafa, símbolos e valores inseridos no comercial e na própria marca, em poucos segundos é possível que identifiquemos qual é o produto e à qual marca se refere, por intermédio dos sentidos e significados agregados.

Nessa cena, o homem cumprimenta outros convidados da festa, o que demonstra que ele é um homem educado, com uma enorme bagagem cultural e que, provavelmente conhece os outros convidados, pois interage com eles, conforme a cultura de cada um. A cena caracteriza um legissigno icônico remático, pois sabemos que os convidados são de países e culturas diferentes, mas não sabemos quais são, exatamente. 
Os símbolos e suas representações na propaganda televisiva: análise semiótica do VT “The Entrance” da Heineken
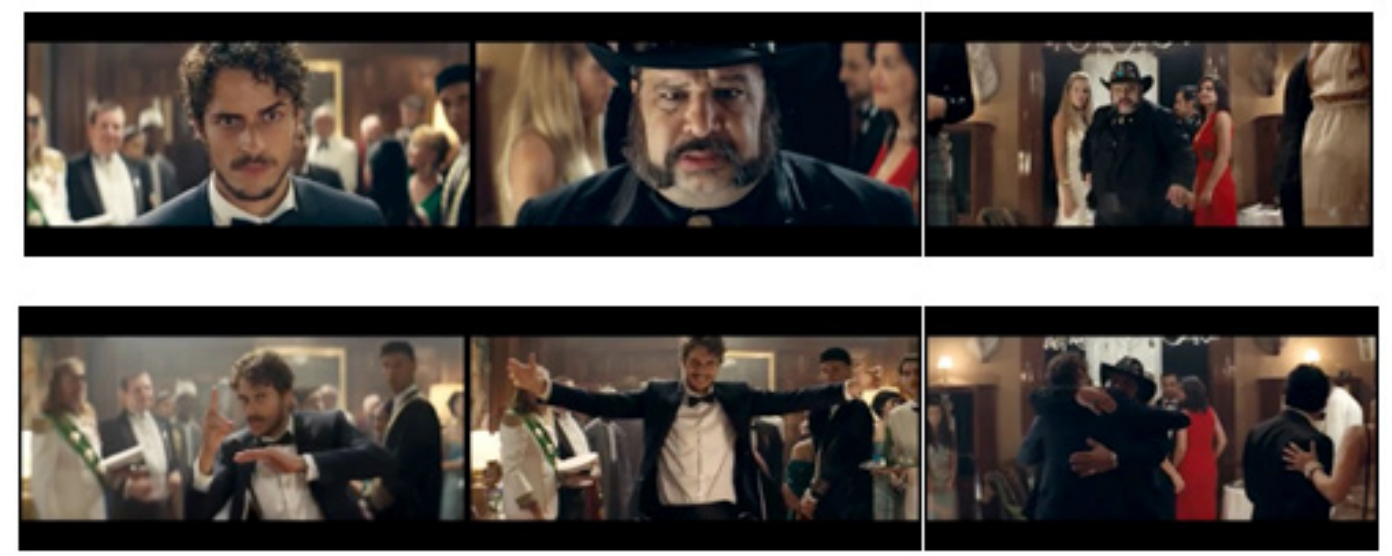

Figura 04 - Decupagem da Cena 04 Fonte: Heineken (2014).

Na cena quatro há um ar de suspense quando há um close no rosto do ator principal que faz uma careta pouco amigável, o que representa um índice já que indica que ele está irritando e em frente há uma pessoa da qual ele não é amiga. Em seguida, surge o inimigo do personagem principal, um xerife que, na mesma feição de inimizade, faz um movimento de retirar algum objeto do cinto, provavelmente uma arma. Essa cena pode ser classificada como um sinsigno indicativo remático, pois é um fato realmente acontecendo; indicativo porque indica que uma briga está acontecendo e remático, pois não sabemos qual é o motivo dela.

O personagem faz o mesmo movimento e uma simulação e tiro sem possuir uma arma real, apenas uma arma imaginária que é idealizada por ele por meio de um movimento de mãos. O xerife cai no braço de duas mulheres bonitas e bem vestidas, que são ícones de uma representação de status e poder. No entanto, logo ele levanta e os dois abrem os braços e caminham em direção um do outro em forma de carinho e em um ato de reencontro. A atitude de abrir os braços é um indício de receptividade e amizade, por isso, essa cena é classificada como um sinsigno indicativo dicente, onde tudo não passou de uma brincadeira.

Aqui, está presente a sedução, onde os fatos que acontecem no decorrer das cenas têm o objetivo de introduzir o receptor no interior da mensagem, fazendo com que produza determinado sentido a fim de fazer com o que o receptor realmente queira fazer parte do mundo da marca. O próximo passo para que a mensagem seja eficaz é agir de forma persuasiva. 
Você acredita que a publicidade nos blogs tem tanta credibilidade quanto a das revistas de moda (Vogue, Elle, Capricho, entre outras)?
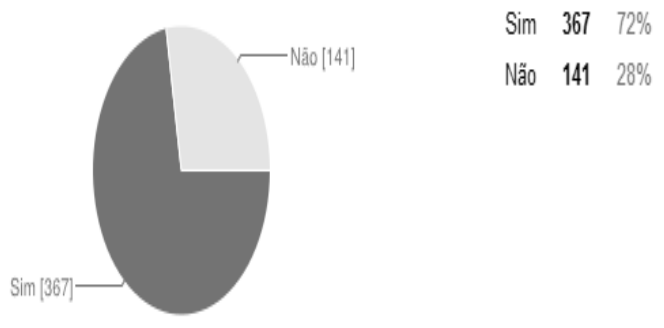

Não $141 \quad 28 \%$

Figura 05 - Decupagem da Cena 05

Fonte: Heineken (2014).

Referente à cena cinco, há mais um momento de suspense, onde o personagem principal é pego de surpresa, mas demonstra suas habilidades ao retirar a toalha da mesa sem derrubar as garrafas de Heineken que estão nela; e o seu cavalheirismo ao utilizá-la para limpar o batom borrado de uma bela mulher. Pode-se classificar a cena como um sinsigno indicativo remático, pois é um fato realmente existindo, que indica um momento de tensão, mas não sabemos exatamente o que está acontecendo ou o que causa esse momento. Analisada a cena cinco e compreendendo quais os elementos semióticos inseridos nela e qual sua finalidade, foi possível analisar a cena seis, que é composta por quatro quadros.

A combinação de trilha, frequência do movimento e elementos cenográficos como iluminação, fornecem à cena um clima de tensão, onde o personagem principal se antecipa aos fatos, mostrando suas habilidades e seu cavalheirismo. No decorrer de todo o comercial, o personagem principal torna-se um modelo a ser seguido.

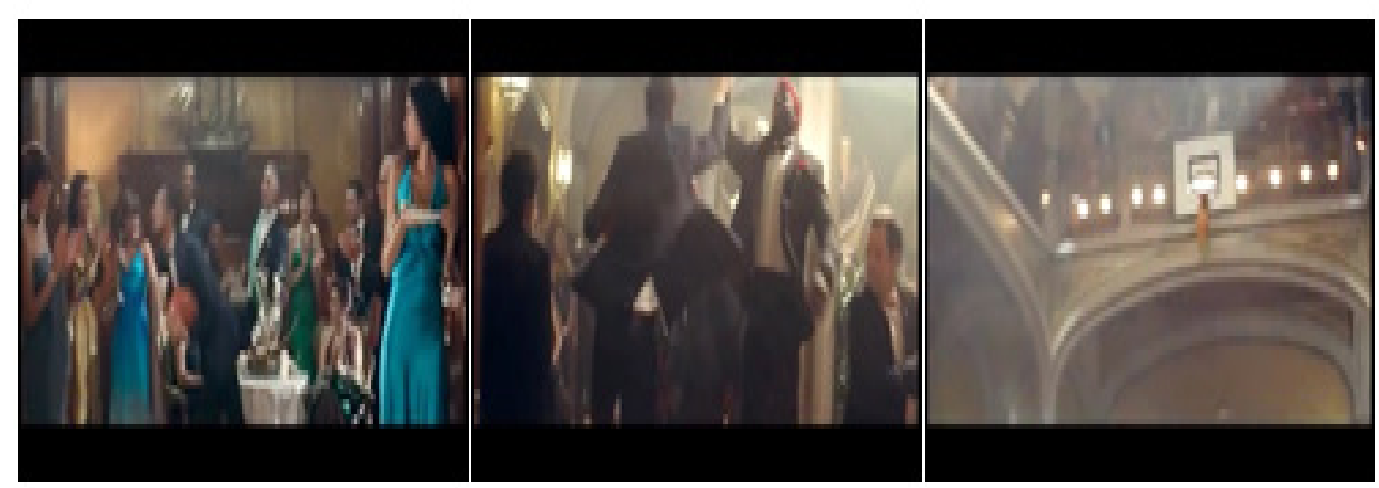

Figura 06 - Decupagem da Cena 06

Fonte: Heineken (2014). 
Os símbolos e suas representações na propaganda televisiva: análise semiótica do VT “The Entrance” da Heineken

Na cena seis, uma bola de basquete é arremessada para o personagem principal, que a segura e corre criando jogadas de um jogo de basquete real, no qual ele interage com outros personagens como se formassem uma equipe. Ao final, ele arremessa a bola e acerta a cesta. Essa cena refere-se a um legissigno simbólico dicente, pois o esporte é algo conhecido universalmente, tornando-se um símbolo e que possui regras invariáveis. A cena faz o expectador participar do clima de competição e adrenalina, provocando interação e prendendo a atenção de quem assiste para saber qual será o final da jogada.

Nessa cena, é possível identificar uma marcante referência da marca, que é uma grande incentivadora do esporte e da música, patrocinando grandes eventos esportivos e festivais de música mundiais, pois acreditam que a marca deve estar onde há momentos de diversão, já que esse é um dos valores da marca.

A imagem se torna muito mais rica, quanto mais sentimentos e emoções estão contidas nas informações (MARTINS, 1999, p. 126). Isso acontece porque a partir da evidência de sentimentos, valores e sensações, as marcas, em sua publicidade, são humanizadas provocando uma aproximação com o público que deseja atingir.
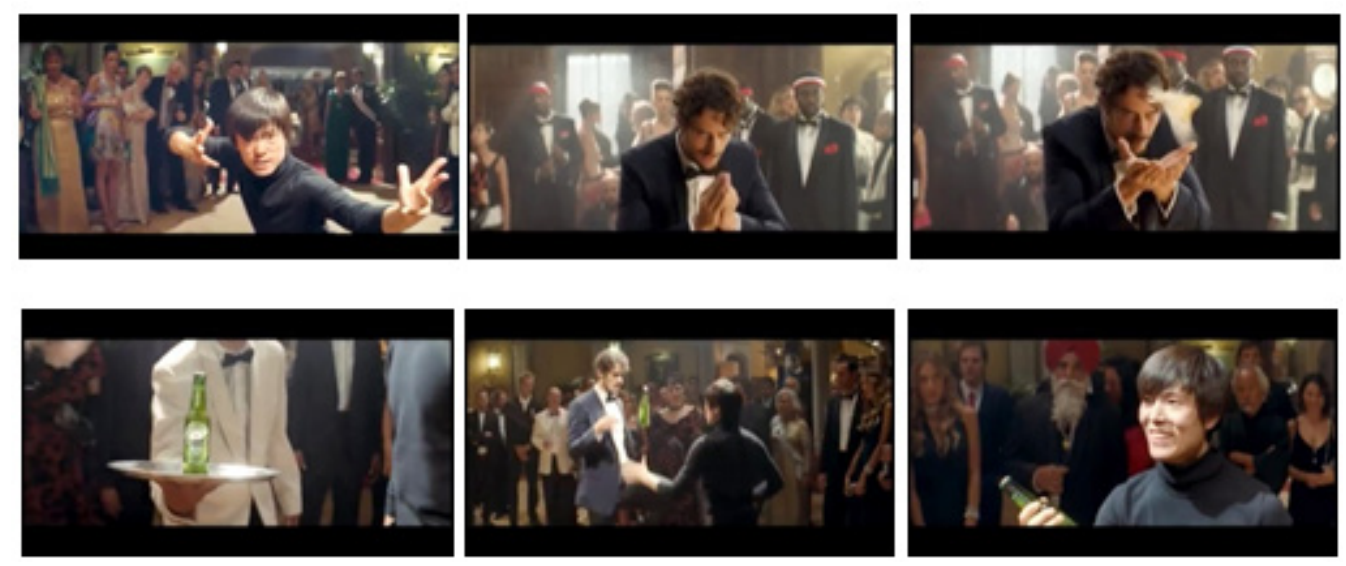

Figura 07 - Decupagem da Cena 07 Fonte: Heineken (2014).

Na sequência do vídeo, na cena sete, entra em cena um ninja, que chama o personagem principal para uma luta. O herói o cumprimenta em um movimento feito no início de lutas em sinal de respeito aos adversários. No instante seguinte, ele solta uma pomba e em seguida faz movimentos e golpes de artes marciais e vai em direção ano ninja. O garçom surge novamente com uma garrafa de Heineken que é disputada pelos dois lutadores. Ao final 
quem fica com a cerveja é o personagem principal, que a entrega ao ninja que, por sua vez, sorri em forma de admiração e agradecimento. Essa cena pode ser classificada como um legissigno simbólico dicente, pois sabemos que está acontecendo uma luta de artes marciais e que a pomba branca representa o símbolo da paz, portanto, aquela não era uma luta real, mas apenas uma manifestação, deixando claro que a predominância da paz naquele ambiente.

Nessa cena, o significado produzido e que está evidente é a paz entre os povos. Desde o início do VT apresentam-se personagens de diversos países com características e culturas diferentes e é através da imagem da pomba, inserida intencionalmente na cena, que a paz é transmitida como um valor agregado à marca.
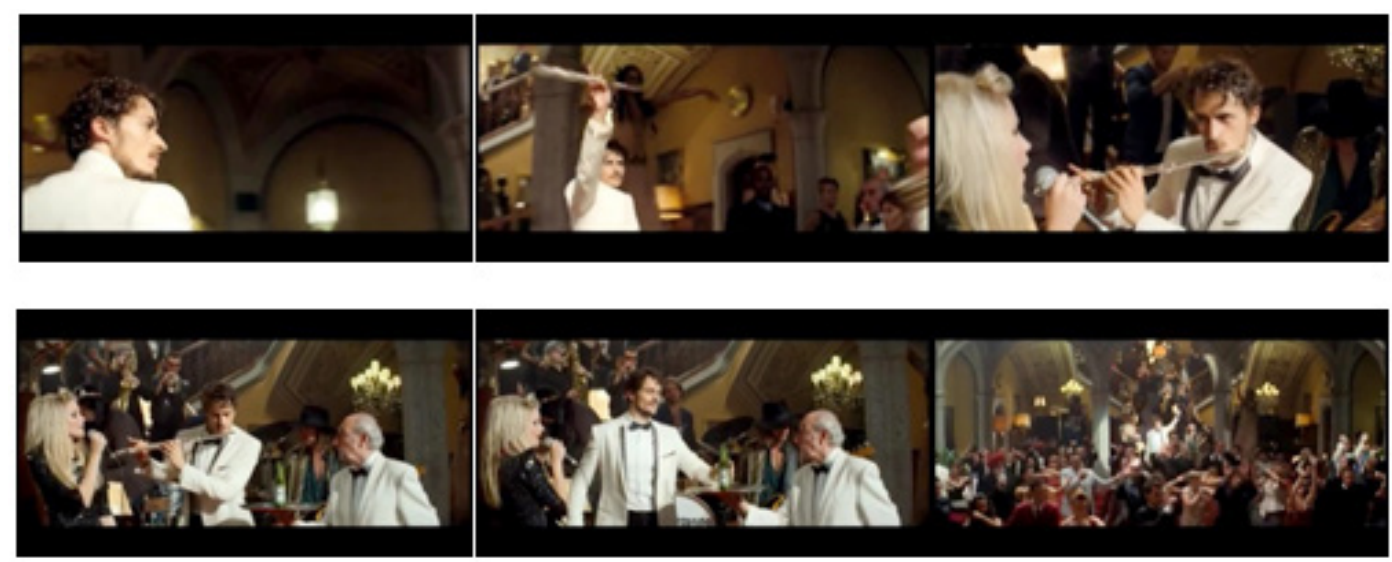

Figura 08 - Decupagem da Cena 08 Fonte: Heineken (2014).

Na cena oito o personagem principal se junta à banda que está tocando na festa e mostra mais uma habilidade tocando flauta. Surge o garçom novamente com uma garrafa de Heineken e dessa vez o herói bebe a cerveja e olha para o rótulo em sinal de aprovação. Em seguida, ergue a garrafa em um gesto de liderança e incentiva os convidados a dançarem em sintonia e no mesmo ritmo. A classificação mais adequada para essa cena é o legissigno simbólico argumental, onde o herói prova a cerveja, faz um gesto de aprovação, que é um símbolo e ergue a garrafa em sinal de comando e status, motivando todos os convidados a dançarem da mesma forma, por mais que sejam de culturas diferentes.

Na cena oito, por fim, é possível compreender a mensagem por completo. Podemos identificar as três estratégias da linguagem publicitária apontadas por Santaella: a sugestão, que tem o objetivo incluir o receptor na mensagem; a sedução, que faz com que o telespectador queria viver os valores 
Os símbolos e suas representações na propaganda televisiva: análise semiótica do VT “The Entrance” da Heineken

da marca e por último, a persuasão, que tem a intenção de fazer com que o consumidor adquira o produto, para que, além de adquirir algo material, adquira também os valores que estão inseridos no produto e na marca.
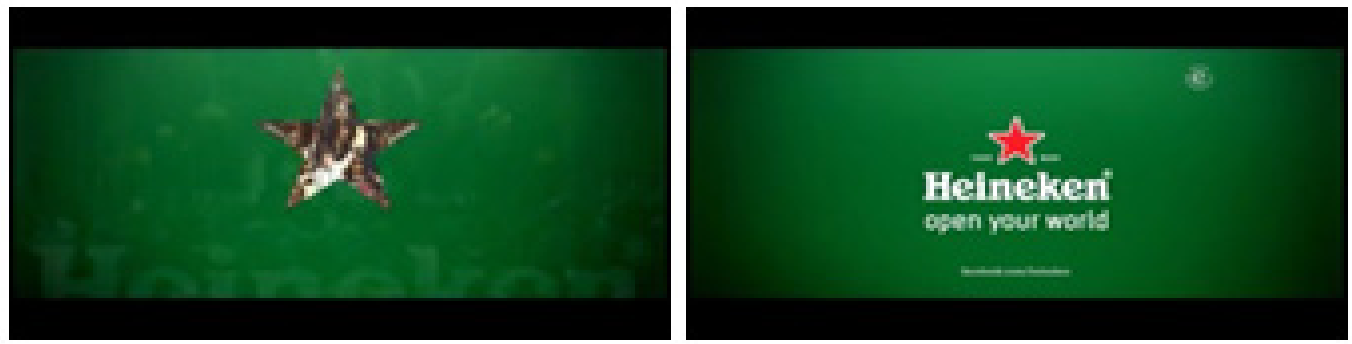

Figura 09 - Decupagem da Cena 09

Fonte: Heineken (2014).

A última cena fecha-se em uma estrela, marca da cerveja, que é um símbolo; e com a assinatura da Heineken. Portanto, essa cena é um legissigno simbólico argumental, pois compreendemos quem é o anunciante e qual a mensagem que o anúncio está transmitindo.

Assim, a composição do comercial de televisão, proporciona um conjunto de experiências, impressões, posições e sentimentos que as pessoas podem apresentar sobre a marca e o produto (PEREZ, 2004, p. 148). Dessa for$\mathrm{ma}$, os signos inseridos no VT, provocam sentidos e significados em quem o assiste e essas pessoas, consequentemente, absorvem os valores da marca.

É possível concluir que a semiótica está presente no VT, a fim de transmitir a mensagem com maior eficácia para que o público expectador a interprete da forma correta. Percebe-se, também que, a produção de sentido contribui de forma fundamental para o processo de codificação e decodificação da mensagem, na medida em que a semiótica nos fornece condições para interpretarmos os significados das coisas.

\section{CONCLUSÃO}

Todas as coisas com as quais temos contato representam alguma forma de comunicação, seja no trabalho, na rua ou na mídia. Para compreender melhor esses processos de comunicação é essencial entender como as mensagens são construídas.

A semiótica, ciência geral de todos os signos, é uma das formas pelas quais podemos compreender o interior das mensagens e os significados que elas estão aptas a produzir, pois penetra na construção estrutural da mensagem auxiliando na sua interpretação. A semiótica foi possível pelos esforços de Peirce (2008), possibilitando, a partir da definição das tricotomias e das 
classes dos signos, compreendermos os signos como elementos que representam outras coisas diferentes dele que possibilitam diversas interpretações de acordo com as circunstâncias e o contexto em que são utilizados.

Tendo como enfoque o VT "The Entrance" da Heineken, buscou-se identificar e analisar os elementos semióticos inseridos no VT, associando os signos à produção de sentido que estão aptos a causar no expectador. Por meio dessa análise, foi possível perceber que os signos auxiliam no processo de construção da mensagem e no entendimento do que está inserido nela, exercendo importante função no processo de persuasão. Além disso, verificou-se que, o papel da associação de som, imagem e movimento é contribuir para a construção de ideias e que, quando bem relacionados, produzem sentidos. Não só a semiótica, mas também outros elementos televisivos possibilitaram uma melhor análise dos dados colhidos.

Pode-se concluir que, quando uma propaganda é desenvolvida, é preciso associar elementos que provoquem sedução persuasiva no consumidor para que ele adquira determinado produto ou concorde com determinada ideia.

O desafio dos publicitários em realizar campanhas eficientes e eficazes está na utilização associada de elementos semióticos e recursos televisivos a fim comunicar a mensagem com clareza e eficácia, para garantir o sucesso da campanha e do anunciante. A associação desses elementos, como som, imagem, movimento, luzes e cortes dão sentido a mensagem publicitária na televisão e, por esse motivo, provocam emoções e criam significado em que a recebe.

Peirce (2008) não concluiu seus estudos ao definir as tricotomias e as dez classes do signo, devido sua complexidade e profundidade. Por isso, o papel desse Trabalho de Conclusão de Curso é também contribuir com os estudos da semiótica associada à comunicação e à produção de sentidos e significados. 
Os símbolos e suas representações na propaganda televisiva: análise semiótica do VT “The Entrance” da Heineken

\section{REFERÊNCIAS}

ECO, Umberto. O signo. 5. ed. Lisboa: Presença, 1997.

HEINEKEN. História e Campanhas. Disponível em: <http://www.heineken.com/br/home. aspx>. Acesso em: 28 set. 2014.

NÖTH, Winfried. A semiótica no século XX. 3. ed. São Paulo: Annablume, 2005.

PEIRCE, Charles S. Semiótica. Tradução J. Teixeira Coelho. São Paulo: Perspectiva, 2008. PEREZ, Clotilde. Signos da marca: expressividade e sensorialidade. São Paulo: Pioneira Thomson, 2004.

PERUZZOLO, Adair Caetano. Elementos de semiótica da comunicação: quando aprender é fazer. Bauru: Edusc, 2004.

SANTAELLA, Lucia. A teoria geral dos signos: como as linguagens significam as coisas. São Paulo: Pioneira, Cengage Learning, 1986. . Estética: de Platão a Peirce. 2. ed. São Paulo: Experimento, 2000. . Como eu ensino: leitura das imagens. São Paulo: Melhoramentos, 2012. . O que é semiótica. São Paulo: Brasiliense, 1999.

SANTAELLA, Lucia. NÖTH Winfried. Estratégias semióticas da publicidade. São Paulo: Cengage Learning, 2010.

TAVARES, Mauro Calixta. A força da marca: como construir e manter marcas fortes. São Paulo: Harbra, 1998. 


\section{Elisangela Antunes}

Cursando MBA em Estratégias de Marketing, possui graduação em Comunicação Social habilitação em Publicidade e Propaganda pela Universidade do Oeste de Santa Catarina - UNOESC. Publicitária atua na Agência de Comunicação Fullgaz Comunicação de Joaçaba.

elisantunes_@hotmail.com

\section{Silvia Spagnol Simi dos Santos}

Mestre em Ciências da Linguagem, possui Especialização em Comunicação e Marketing, Especialização em Novas Mídias, Rádio e TV, MBA em Estratégias de Marketing e Graduação em Publicidade e Propaganda. É Coordenadora do curso de Publicidade e Propaganda da UNOESC e do MBA em Estratégias de Marketing da UNOESC Joaçaba. Professora em várias disciplinas, tem experiência na área da Comunicação com ênfase em Programação Visual, Produção Gráfica, Web Design, Planejamento Publicitário e Semiótica. silvia.simi@unoesc.edu.br

RECEBIDO EM: 03/07/2015

APROVADO PARA PUBLICAÇÃO: 06/10/2015 